Article

\title{
Competences of Graduates of Higher Education Business Studies in Labor Market I (Results of Pilot Cross-Border Research Project in Poland and Slovakia)
}

\author{
Magdalena M. Stuss ${ }^{1, *}$, Katarzyna Szczepańska-Woszczyna ${ }^{2}$ and Zbigniew J. Makieła ${ }^{1(0)}$ \\ 1 Institute of Economics, Finance and Management, Jagiellonian University, 31-007 Krakow, Poland; \\ zbigniew.makiela@uj.edu.pl \\ 2 Department of Management, WSB University, 41-300 Dąbrowa Górnicza, Poland; k.szczepanska@edu.pl \\ * Correspondence: magdalena.stuss@uj.edu.p1
}

Received: 22 June 2019; Accepted: 24 August 2019; Published: 12 September 2019

\begin{abstract}
The analysis of the experiences of cross-border countries shall facilitate the identification of the most helpful and useful tools to improve the process of adaptation of young people into the labor market. The goal of the higher education system, as part of cross-border cooperation, is to develop professionally competent, service-oriented, principled and productive citizens in Poland and Slovakia. There are a lot of factors influencing the possibility of undertaking rewarding jobs by students and graduates that are related to their degree, especially the supply and demand of business related jobs which plays a significant role in the process. The analysis of degree programs, the views of working students, graduates and employers, followed by the preparation of a research report and relevant recommendations may have a beneficial effect on the profile and quality of education and the future of graduates in the countries included in the study, as well as in other countries which are interested in the outcomes of the project. The objective of this article is to present the results of research on how graduates of higher education business studies develop in terms of the skills, knowledge and characteristics which enable them to be employable in Poland and Slovakia. The applied research methodology combines the analysis of subject-related literature with empirical research. The questionnaires for data collection constituted a survey for independent completion. The adopted method allowed a numerical description of trends, attitudes and opinions in a selected group. It also facilitated a comparison of the results of the studies of Polish graduates and Slovakian graduates.
\end{abstract}

Keywords: competences; cross-border education; graduates; labor market

\section{Introduction}

In recent years, higher education systems have faced growing pressure and various challenges about how to prepare students for the labour market. The goal of the higher education system, as part of cross-border cooperation, is to develop professionally competent, service-oriented, principled and productive citizens in Poland and Slovakia. Students should have the opportunity to develop competences during their studies in order to be employable in the labour market.

The analysis of the experiences of cross-border countries will facilitate the identification of the most helpful and useful tools to improve the process of adaptation of young people into the labour market.

The analysis of degree programs, the views of working students, graduates and employers, followed by the preparation of a research report and relevant recommendations may have a beneficial 
effect on the profile and quality of education and future of graduates in the countries included in the study, as well as in other countries, which are interested in the outcomes of the project.

There are a lot of factors influencing the possibility of undertaking rewarding jobs by students and graduates that are related to their degree. Supply and demand for business-related jobs play an important factor in the process. Nevertheless, the quality of education and the meeting of employer expectations also plays a very significant role and this is the focus of this research. That is why more attention has been paid, in recent years, to the importance of various types of competencies required in the labour market.

The Higher Education Institution needs to develop talented graduates who will be able to adapt to the changing conditions of the job market resulting from global competition. Universities need to identify the skills that will be useful for their graduates for a lifetime and allow them to succeed in the labour market for different industries.

The literature characterizes only the general problem of key competences of students and graduates. The gap is, however, the lack of comparisons of key competences in cross-border systems.

The aim of the research was to analyse the key competences of lifelong learning at the business school graduates in Poland and Slovakia. The aim of the research was to analyse the key competences of lifelong learning at the business school graduates in Poland and Slovakia. In the future, research will allow the preparation of changes in the university programs. This will allow unification of obtaining key competences by university graduates on both sides of the border and thus employment opportunities both in Poland and in Slovakia. Two main research questions were formulated to achieve this aim:

- Which competences were acknowledged to be the most significant among the Polish and Slovakian graduates?

- Is there a similarity or identity, or the complete reverse in terms of differences between the Polish and Slovakian graduates?

Finding answers to those research questions may facilitate an understanding of the professional competences of graduates residing in the cross-border areas better due to the possibility of obtaining work on both sides of the border and enhancing the business school/faculty curriculum.

The presented research was of a pilot project nature and in order to gain a broader spectrum it shall be repeated on a larger sample group.

\section{Internationalism}

Defining cross-border cooperation is the conditioning of the multiplicity of the activity of actors and entities of cooperation in relations between the beneficiaries of these networks. The paradigm of cross-border cooperation is the shaping of long-lasting, multi-level relations in cooperation between the borderland areas, while the result is the neighbourly relations between the local communities [1]. Such a perception of cooperation is an element of the strategy of internationalism and corporate social responsibility (CSR — corporate social responsibility, including the local beneficiaries of this strategy). The recipients are self-government units, organizational entities and units created by the state, provincial governors or self-government units, NGOs, chambers (economic, trading and handicrafts), colleges, schools and public organizations conducting activities such as educational, research institutions, culture, churches, religious denominations, and individual recipients. The differentiation of the beneficiaries of the cooperation defines the goals that are supporting the sector of SMEs, protection of the natural environment, access to transportation, IT and communication networks, ties between the city and rural areas, health care, access to the institutions of culture and education, and cooperation with public administration and development of social capital.

The notion of internationalism has been regulated since 1980 by the European Framework Convention of cross-border cooperation between communities and territorial authorities (European Outline Convention on Trans-frontier Co-operation between Territorial Communities or Authorities 
1980) [2-4]. (On 21 May 1980, a convention agreement was drawn up in Madrid relating to cross-border cooperation between territorial communities and authorities with the following wording: European Framework Convention of cross-border cooperation between territorial communities and authorities). In the preamble, it was indicated that "the member states of the European Council which signed the convention, while taking account of the experience that showed that the cooperation between the local and regional authorities in Europe facilitates the execution of their goals, particularly leading to the improvement of the state and development of the borderland areas, are decidedly in favour of supporting this cooperation to the broadest extent and in this way lead to economic and social development of the borderland areas, while also strengthening the feeling of the community which unites the nations of Europe" (Law Gazette 1993 no. 61 pos. 287).

In the process of shaping the process of internationalism, defined in the herein paper as cross-border cooperation, the priority domination is directed at the self-governing and public local and regional authorities, usually in the borderland areas, which play a decisive role in developing and standardizing the networking of cross-border services that are appropriate, effective and problem-free. Understanding what results from the legislative effects of community law causes the fact that internationalism which is strengthened by the network ties of regional structures has certain limitations. Living in another country of the EU is not a sufficient condition for availing of the right of free movement and free flow of employees.

In the process of internationalism, an important instrument that regulates these relations is the European Territorial Cooperation (ETC), whose activities within the framework of the EU policies of cohesion serve the support, promotion and execution of the common projects of an international nature within the European Union [5]. This cooperation is executed on three levels [5,6]:

- Cross-border cooperation whose aim is to initiate, shape and execute the common local and regional initiatives,

- Transnational cooperation directed at the territorial integration of the EU by supporting availability, sustainable development of urban areas, entrepreneurship, innovativeness and protection of the natural environment,

- Inter-regional cooperation executed on the basis of at least several formal bilateral agreements and multilateral networks, international associations and projects financed by the EU. This cooperation facilitates the exchange of experience and good practices in the sphere of the labour market, cross-border security, educational and cultural cooperation, tourism, support for innovativeness and the economy based on knowledge and environmental protection.

\section{Features of Internationalism}

The hyponymy of cross-border cooperation is internationalization, worldiness, globality, worldwide, and transnationality. The efficient execution of cross-border cooperation in the territories of the EU is an organizational challenge whose aim is to strengthen economic cohesion, as well as social and territorial cohesion. The European Grouping of Territorial Cooperation (EGTC) was founded for the purpose of executing the stipulated aim. This is a legislative instrument whose potential may help to achieve significant progress in the field of cross-border cooperation in the forthcoming years [7-9].

The legislative regulation relating to the EGTC may be found at EU level in the regulations of the directive of the European Parliament and EU Council dated 5 July 2006. (The Directive (EC) no. 1082/2006 of the European Parliament and European Council dated 5 July 2006 relating to the issue of creating the European Grouping of Territorial Cooperation, Journal of Laws WE L 210/19 dated 31 July 2006 (hereinafter: Directive relating to EGTC). The primary legislative basis for the issuance of this directive constituted art. 159 paragraph three of the Treaty establishing the European Community). This directive was subsequently amended by the directive of the European Parliament and EU Council No. 1302/2013 dated 17 December 2013 (the Directive of the European Parliament and European Council (EU) no. 1302/2013 dated 17 December 2013 amending the Directive (EC) no. 1082/2006 relating to the issue of the European Grouping of Territorial Cooperation (EGTC) with the aim of clarifying, 
simplifying and streamlining the process of creating such groupings and their functioning, Journal of Laws EU L 347/303 dated 20 December 2013. The amendments were implemented with the directive relating to EGTC that came into being on 22 June 2014) and implemented into national law first and foremost by the Act dated 7 July 2008. (In terms of matters unregulated by the directive relating to EGTC and in the enacted law, the regulations of the Act dated 7 April 1989-law of associations are applied).

The legislative regulations of cross-border cooperation are important as it is usually the case that varying organizational and administrative structures function in different countries, while its bodies are equipped with the competences of differentiated range and scope [10].

Cross-border cooperation is limited by asymmetry at the level of the economic development of the neighboring countries, particularly relating to the borderland areas in which the states functioned in market economy systems and centrally controlled systems in the not too distant past [11-13]. An example of the variability of the economic structures is the Euroregion of the Baltic area, which is an institutionalized form of cross-border cooperation in the south-easterly region of the Baltic Sea. This encompasses regions of states of a market economy orientation (Denmark and Sweden) and regions of states of a centrally planned orientation (up to 1990) (Lithuania, Poland). The longstanding differences in the economic systems are visible in terms of, among others, the level of GDP per capita, the standard of living of inhabitants, the magnitude of unemployment, innovativeness of the economy, which all represent unfavourable indicators for the borderland areas of the regions of Central and Eastern Europe [14].

The barrier to cross-border cooperation (see: Table 1) is that of the incohesive systems of technical and economic infrastructure shaped in the past, e.g., the differentiated width of railway tracks, the quality of roads, the lack of motorways that restricts transit traffic, particularly in mountainous areas. With regard to the technical barriers to regional cooperation, it is necessary to indicate the insufficiently developed communication network, the banking infrastructure, while also tourist and telecommunications infrastructure in the post-communist countries [13,15]. It is first and foremost essential to build the transit routes, while also extend the existing routes and build new border crossing routes. Ports and airports also require modernization [16,17].

Table 1. Chosen barriers to internationalism.

\begin{tabular}{|c|c|}
\hline $\begin{array}{l}\text { Historical } \\
\text { experience }\end{array}$ & $\begin{array}{l}\text { Effects of policies conducted by Germany and the Soviet Union during and after World } \\
\text { War Two. } \\
\text { Nationalistic tensions first and foremost associated with the regulations on minority rights. }\end{array}$ \\
\hline Nature & Protection of natural environment. Lack of integrated plans for spatial management. \\
\hline Demographic & $\begin{array}{l}\text { Low birth rates, aging of inhabitants, low level of population density, relatively low level of } \\
\text { urbanization, as well as great inequality in terms of spatial distribution of settlements. }\end{array}$ \\
\hline $\begin{array}{l}\text { Administrative } \\
\text { and legislative }\end{array}$ & Harmonization of law. \\
\hline Cultural & $\begin{array}{l}\text { Linguistic differences. Lack of integrated programs in sphere of culture, safety and systems } \\
\text { of euro-regional education. }\end{array}$ \\
\hline Economic & $\begin{array}{l}\text { Disproportion in economic potential and standards of living between particular countries } \\
\text { of the region. } \\
\text { Infrastructure of border crossings. Lack of integrated systems of infrastructure. } \\
\text { Lack of integrated sustainable development. }\end{array}$ \\
\hline
\end{tabular}

(Source: Self-analysis).

The ecological infrastructure is in the sensitive group of backwardness in terms of tangible infrastructure, due to the insufficient number and inadequate quality of water treatment plants and recycling of municipal waste, while also the low level of the utilization of the renewable sources of energy. A serious barrier to the process of cross-border cooperation is the profound difference in terms 
of the awareness of the ecological needs, while also the necessity of implementing the innovative solutions of the management of resources in terms of building participatory needs of local management.

Cross-border cooperation is a form of international cooperation between local and regional communities, international communication, building relations of an organization, society and people of other cultures, municipal cooperation that transcends the state borders (Korczak, Nowacki, 2006) [18], in which its fundamental element is the "mutual participation of authorities and local communities in resolving common problems" [19]. This is reinforced by common projects of the self-governing units of the neighboring countries [20].

Cross-border cooperation may be defined as cooperation of local communities and regional communities that take account of all the manifestations, forms and areas of the self-organization of the communities [21,22], in which the common feature of internationalism is characteristic, which signifies "the neighbouring borderland areas that belong to several states" [23]. Furthermore, the determinant of cross-border cooperation is the notion of a border [24], which determines the geographical proximity of its participants [24], while the aims of creative cooperation should be fulfilled by an administrative nature only.

In the European Union, the intensified processes of regionalization is being observed, which is the effect of the process of integration, whereas the borders between states are of an administrative dimension and are becoming more open. We may observe the dynamic process of cooperation extending beyond the state borders, in which Euroregional cooperation is becoming an increasingly perfect form of cooperation and communication between inhabitants on both sides of the borders. There is a form of cooperation between the authorities, self-governing communities and organizations of two or more neighboring countries which is distinguished by a higher degree of the institutionalization of the structures of cross-border cooperation [25].

The development of Euroregions is conducted in the area of structural changes, in which the councils of Euroregions are formed, as well as secretariats and employee groups. The shaping of the network ties and economic entities, specialized institutions and international bodies for the coordination of cross-border cooperation restricts the monopoly of states. The development of Euroregions is the result of the needs of local communities, whereby they resolve common problems connected with infrastructure, while also enhancing the level of economic growth, the development of tourism, environmental protection, breaking economic and socio-cultural barriers and also removing the effects of catastrophes that are a threat to the health and life of the people living in these regions.

A better communicative availability and high level of quality of the natural environment are the fundamental premise of the development of economic and social undertakings. They lead to the enhancement of the attractiveness of the borderland areas for the inhabitants, foreign and domestic investors, as well as tourists. Reinforcing the cross-border communication ties also leads to the development of the ties between the borderland areas in both the economic and social spheres, which favours the creation of a cohesive area (see: Table 2). 
Table 2. Areas of cross-border cooperation.

Economic cooperation

Creating the cross-border networks of ties (cooperation networks) in various spheres of the economy, as well as between enterprises and research institutions favours the economic growth of this area, as well as improving its attractiveness as a location.

Supporting entrepreneurship by means of creating the conditions for the development of micro-sized, small and medium-sized enterprises leads to the enhancement of the competitiveness of this area and shall constitute its competitiveness, particularly in the sector of services renders its further employment growth possible. The growth in SMEs may therefore lead to the creation of new workplaces and ease the existing problems on the labour market on the borderlands. Tourism takes up the traditionally significant places in the economy of the borderlands due to the longstanding traditions of this area, conditions of nature, as well as with regard to its geographical location. Tourism, particularly in the areas bordering Poland and the Czech Republic may constitute a significant factor in stimulating economic growth and may also lead to the improvement of their opportunities for development.

Scientific, educational Network cooperation of entities in the sphere of science and education. Social and cultural exchange between the inhabitants.

Modernization and development of the communication infrastructure of a local and regional significance in the borderland areas (e.g., roads, modernization of railway infrastructure with the aim of improving safety, or increasing the availability of

Reinforcing communication access transportation in the area, adaptation of the borderland infrastructure for new needs), improvement of communication service of the borderland areas, creating integrated communication systems (public transport, etc.).

Supporting development and modernization of infrastructure of environmental protection (water supplies, sewage treatment plants, sewage system, waste

Environmental protection management, power supply, supporting renewable sources of energy), care of nature and landscape (biodiversity, revitalization of local significance, long-lasting care and prophylactics of ecological damage, water ecosystems, water retention in the area, ecological stability).

Supporting development, prophylactics of environmental and technological threats,

Improvement of supporting activities associated with monitoring and reacting to environmental threats (e.g., prophylactics, elements of nature, floods, prophylactics of ecological damage, education and environmental education) and exchange of experiences.

safety

Cross-border traffic of patients, reimbursement of costs incurred in association with

Cross-border health care acquisition of health benefits in another member country of the EU. The rights of a patient in cross-border medical care.

Source: Self-analysis.

\section{Research Method}

Analysis of the internationalism and cross-border cooperation issues allowed to draw a background for the planned research area. The next step of our methodology is a literary review about key competences and lifelong learning. Competences are the collection of knowledge and skills mobilized for action and depend to a large extent on the context of the process of management. Thus, they should be described as precisely as possible by taking account of the context, particularly the allocated resources, means and conditions of executing activities availed of in practice and the expected results. In subject-related literature, a wide range of approaches function in terms of defining competences (see: Table 3), yet not all are observable and possible to describe and therefore it is necessary to come to terms with the existence of a margin of uncertainty, while also the necessity of making predictions if it relates to the application of these competences in other circumstances, as well as in other work positions. 
Table 3. Review of chosen definitions of notions of competences.

\begin{tabular}{|c|c|}
\hline $\begin{array}{l}\text { Longman Dictionary } \\
(1989)[26]\end{array}$ & $\begin{array}{l}\text { Competence is perceived as the ability to execute something that is necessary, } \\
\text { skills. }\end{array}$ \\
\hline $\begin{array}{l}\text { Słownik języka polskiego } \\
\text { (Dictionary of Polish } \\
\text { language-2005) [27] }\end{array}$ & $\begin{array}{l}\text { Competence is the range of powers of attorney and authorizations, the scope of } \\
\text { activities of the body of power or organizational entity; the scope of someone's } \\
\text { power, skills and responsibilities. }\end{array}$ \\
\hline $\begin{array}{l}\text { D.C. McClelland (1990) } \\
\text { [28] }\end{array}$ & $\begin{array}{l}\text { The competences held by employees consist of: Knowledge, skills, abilities and } \\
\text { personality features that are necessary for the appropriate execution of work. }\end{array}$ \\
\hline Hartog (1992) [29] & $\begin{array}{l}\text { Competences are described as talents, skills, and capabilities of graduates that } \\
\text { contribute to productivity gains and are a key element for sustainable economic } \\
\text { growth and development of the economy. }\end{array}$ \\
\hline Mingotauda (1994) [30] & $\begin{array}{l}\text { Competence is observable and measurable resultant total of knowledge and skills, } \\
\text { acquired, mastered and applied in practice, mobilized by an individual to resolve } \\
\text { a professional problem. }\end{array}$ \\
\hline $\begin{array}{l}\text { Thierry \& C. Sauret (1994) } \\
\text { [31] }\end{array}$ & $\begin{array}{l}\text { "Competence is the ability of an individual to take action leading to the } \\
\text { achievement of the intended aim in the particular conditions with the aid of } \\
\text { specified means". They are not therefore a synonym for qualifications in the } \\
\text { colloquial meaning, nor are they the equivalent of a formal education or diploma. }\end{array}$ \\
\hline Lévy-Leboyer (1997) [32] & $\begin{array}{l}\text { Competences relate to the integrated use of the abilities, personality traits, while } \\
\text { also the acquired knowledge and skills leading to the successful execution of the } \\
\text { mission within the framework of the enterprise. }\end{array}$ \\
\hline $\begin{array}{l}\text { Masten and Coatsworth } \\
\text { (1998) [33] }\end{array}$ & $\begin{array}{l}\text { Competences have a 'dual' meaning. Firstly, there is a track record of } \\
\text { achievement (competent performance) and secondly, an individual has the } \\
\text { capability to perform well in the future which may be understood as good } \\
\text { adaptation and not necessarily superb achievement. }\end{array}$ \\
\hline Pocztowski (2003) [34] & $\begin{array}{l}\text { Competences are identified with qualifications, which encompass the sum total of } \\
\text { the long-lasting human features creating a relation with the high level of effects } \\
\text { achieved by an employee that are of a universal dimension. }\end{array}$ \\
\hline Bratnicki (2000) [35] & $\begin{array}{l}\text { Competence is the multiplicity of technical and managerial integration and other } \\
\text { professional knowledge, together with the abilities and processes. Competences } \\
\text { are of a more strategic nature than an operative one. Their principal aim is to } \\
\text { render specific responses possible, while in general terms the execution of the } \\
\text { strategic intention. }\end{array}$ \\
\hline Oleksyn (2010) [36] & $\begin{array}{l}\text { Competences as a collection of the knowledge held, as well as the abilities, styles } \\
\text { of activities, personality features of interest, } \\
\text { while also a multitude of other factors and features which are availed of and } \\
\text { developed in the processes of work and are to lead to the achievement of the } \\
\text { organizational goals. }\end{array}$ \\
\hline Kim\&Kim (2016) [37] & $\begin{array}{l}\text { Competence may also be described as the individual ability to adapt to changes } \\
\text { in society }\end{array}$ \\
\hline Lee and Park (2017) [38] & $\begin{array}{l}\text { Competence has been defined as the basic ability required to perform the } \\
\text { necessary actions to solve a particular problem. }\end{array}$ \\
\hline
\end{tabular}

Source: Self-analysis.

Generic competences consist of skills needed in a range of contexts, positions, and functions that can be used in an interdisciplinary way to apply and to transfer knowledge, as well as to manage unanticipated requirements $[39,40]$.

Becker suggested that in the context of higher education, competences should be divided into two categories [41]. The first group-generic competences that are a combination of competences providing a strong basis for further learning including learning abilities, problem-solving and analytical competencies. The second group-specific competences that consists of vocational or field-specific ones. On the other hand, Kellermann classifies competences according to five groups, featuring an academic personality, general-academic (represented through the competence of 
general knowledge) [42], scientific-operative (represented through accuracy, attention to detail), personal-professional (represented through field-specific knowledge of methods), social-reflexive (represented through leadership) and physiological-handicraft (represented through manual skills). In addition, competences are often classified according to specific settings such as industry, job, company $[40,43]$.

The research conducted is concentrated on the general activities and requirements associated with work, which reflect the general competences necessary on the labor market and thus, for further research we have adopted the assumptions of the OECD, which perceives competences as central learning outcomes of higher education, which graduates and jobholders must possess to master the modern working environment [44].

Research on 'lifelong learning' reveals a very rich concept in terms of evolution, meanings, forms, benefits and coverage. Although lifelong learning has been the subject of intense policy discussion and development, the concept is not new. The term "lifelong education" originated in England in the 1820s and replaced the term "lifelong learning" in contemporary pedagogical theory and educational practice [45]. Subsequently, UNESCO was the major force in promoting the global discussions of lifelong learning, strongly promoting the idea that education should occur universally and across the lifespan, and should not merely be formal education for the "privileged few" and it was in 1965 when UNESCO International Committee for the Advancement of Adult Education was established while availing of the term 'lifelong education' to describe its initial concept of learning throughout life. Paul Lengrand, the head of the Division of Adult Education at UNESCO, as well as the Director of the UNESCO Institute for Education (UIE) has a special contribution to building the concept of 'lifelong education' in his work "An Introduction to Lifelong Education" [46].

Another important step in defining the concept was the meeting in Vienna in 1998 where the commitment to making the concept of lifelong learning a reality was emphasized and the aims of the existing notions of lifelong learning were clarified. The summit articulated the four pillars of lifelong learning for the EU: Employability, entrepreneurship, adaptability and equal opportunities (European Commission, 1999) [47]. The work was then continued under the Lisbon Special European Council as the fact that workforce competition within the European market was rising due to the renowned 'globalization' notion; and the growing importance of Information and Communication Technologies (ICT) in all sectors of life demands a thorough and at times exhaustive examination of the educational system in Europe for potential reform, along with the guaranteed lifelong learning opportunities [48].

In 2006, the European Parliament and the European Council adopted the Recommendation on Key Competences for Lifelong Learning. It provided a common European reference framework on the key competences for policymakers, education and training providers, the social partners and learners themselves. Furthermore, it hoped to support other related policies such as employment and social policies and other policies affecting youth. To even more effectively accomplish that aim, thus contributing to an efficiently innovative and knowledgeable Europe, the Commission set up a Lifelong Learning Programme having officially launched its action plan in September 2007 [49].

As a result of the aforesaid activities, the competence for lifelong learning models and competence-based education have become widespread throughout different fields of education as a central, strategic tool for educational development and integrating education with training and lifelong learning [50].

In our research, we adopted the latest EU directive published in January 2018 as the new Recommendation on Key Competences for Lifelong learning. The Council Recommendation on Key Competences for Lifelong Learning was adopted in May 2018 [51]:

- Recommendation on Key Competences for Lifelong Learning

- Commission Staff Working Document on Key Competences for Lifelong Learning

- Factsheet on Key competences for lifelong learning. 
The European Reference Framework of Key Competences for Lifelong Learning defined eight key competences [52]:

- Communication in the mother tongue;

- Communication in foreign languages;

- Mathematical competence and basic competences in science and technology;

- Digital competence;

- Learning to learn;

- Social and civic competences;

- Sense of initiative and entrepreneurship;

- Cultural awareness and expression.

The subsequent step of our methodology was a comparative analysis of the results of similar studies. Its omission was observed in the hitherto research conducted on the problematic issues of the standards of competences prepared by the EU in terms of young people [53]. The execution of analysis related to only the society as a whole of the member states. Likewise, they were not taken into account in the methodologies of research of the strict approach towards the employment of the graduates of business schools and as commonly known, this is a significant group of graduates that enter the labor market every year. Based on the aforementioned research loophole, the main aim of the research was indicated as the analysis of the competences of business school graduates in Poland and Slovakia inhabiting the borderland area with regard to the possibility of acquiring work on both sides of the border. Two main research questions were formulated to achieve this aim:

- Which competences were acknowledged to be the most significant among the Polish and Slovakian graduates?

- Is there a similarity or identity, or the complete reverse in terms of differences between the Polish and Slovakian graduates?

Furthermore, the supplementary questions are as follows:

- Which competences are insignificant and may be omitted?

- Which area is prevalent and which area is underrated by graduates in the division of eight key competence areas?

- What formal tools (programs, agreements, grants, or courses, etc.) within the framework of cross-border cooperation may I support with the competences acquired?

During the research process the new questions arose and new research approaches have been created or old ones were adopted to the new requirements. In addition, data collection included the aspect of joint participation, the inductive bottom-up analysis and the interpretation of the collected data [54]. The assumptions made it possible to conduct the collection of thoughtful and complete data as they originate from numerous sources and make triangulation of data possible. The validation of the accuracy of information (approach proposed by Creswell [55]) consisted of a number of stages. At the beginning, the data for analysis was prepared by ordering the data from the selected lifelong learning competencies, and subsequently they were divided into specific categories, depending on the characteristics. The second step was to review all results to acquire general information and reflect upon the common meaning of individual information. This was followed by detailed analysis, which had been preceded by explaining the information obtained in the context of the previously posed research questions and the presentation of individual lifelong learning competences. The aforementioned procedure increased the accuracy of results because it combined information from various sources and led to the allocation of data to specific categories of competences.

Data collection was based on a questionnaire consisting of closed questions. It was assumed that there are no good or bad answers and completing the questionnaire would allow the respondents to understand their own strengths, competences and expectations of the labour market and areas of 
development in terms of key competences. The core key competences of lifelong learning measurement tool were selected, modified, and reconstructed according to the current student characteristics. Each item was structured for evaluation using a seven-point scale to evaluate the usefulness of specific competences.

The last stage of the analysis of data was the interpretation of the results. The adoption of the aforementioned methodology made it possible to create a set of recommended good practices for the business schools located in the cross-border area.

\section{Research Findings}

During the research, we availed of the probability sampling techniques because this may specify the probability that a participant will be selected from a population group. By obtaining this sample with the probability techniques, it may be reasonably ascertained that a sample is representative of the population. The selection procedure was replicated by others to obtain similar samples. Thirty students of the last semester of business studies took part in the research (25 Slovakian students and 25 Polish students). They were both full-time and part-time students between the ages of 23 and 25 .

The detailed test results are included in Table 4 and Figure 1.

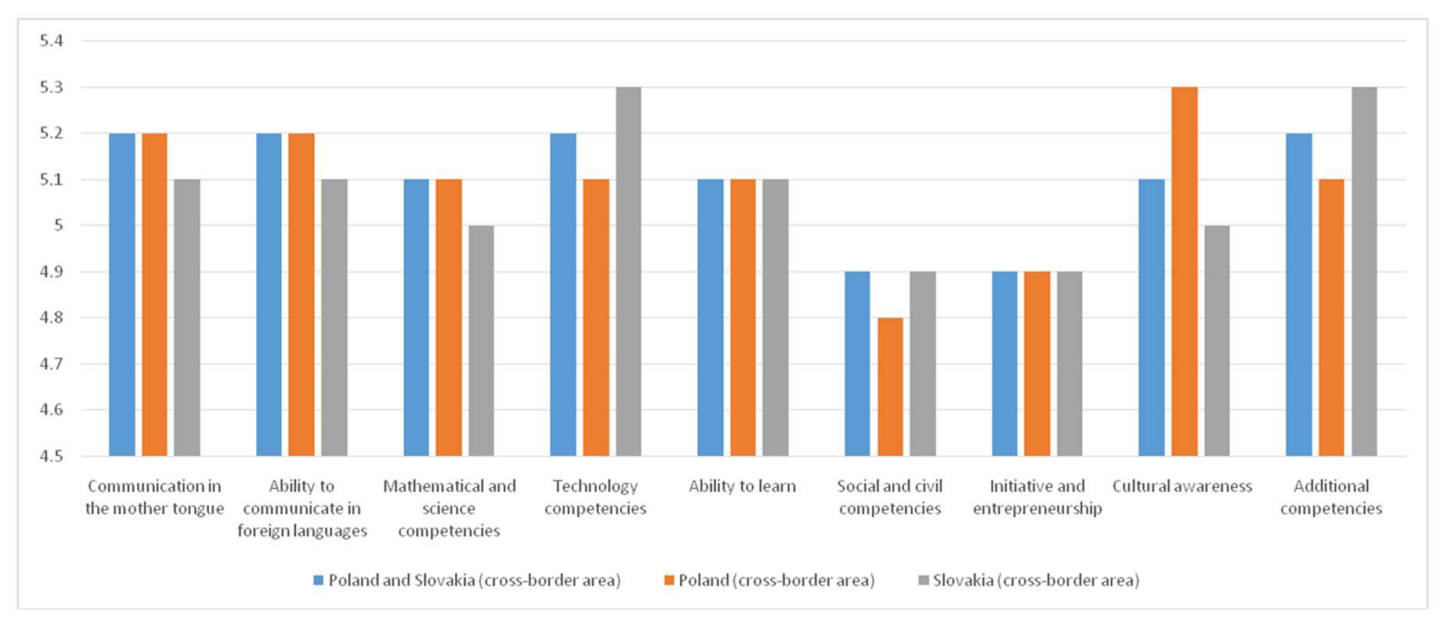

Figure 1. Average results.

The acquired results facilitate the answers to the research questions set out. In terms of the most important competences, the following categories were acknowledged to be important on the labour markets by the respondents:

- Communication in the mother tongue-in particular, the ability to communicate effectively,

- Ability to communicate in foreign languages-in particular English and other languages,

- Technology competences,

- Additional competences, in particular experience.

However, social and civil competences, such as the ability to build relationships with customers and empathy were indicated to be the least important.

Nevertheless, it is necessary to note that none of the groups of competences are dominant. On a scale of seven degrees, all of them received almost five points, or just slightly above five points. 
Table 4. Research results.

\begin{tabular}{|c|c|c|c|c|c|c|c|}
\hline \multicolumn{2}{|c|}{ Poland and Slovakia (Cross-Border Area) } & \multirow{2}{*}{$\begin{array}{c}\text { Average } \\
5.1\end{array}$} & \multirow{2}{*}{$\begin{array}{c}\text { Average from } \\
\text { Category }\end{array}$} & \multirow{2}{*}{$\begin{array}{c}\begin{array}{c}\text { Standard } \\
\text { Deviation }\end{array} \\
0.86\end{array}$} & \multirow[t]{2}{*}{$\begin{array}{l}\text { Standard } \\
\text { Deviation }\end{array}$} & \multirow{2}{*}{$\begin{array}{c}\text { Median } \\
5\end{array}$} & \multirow{2}{*}{ Median } \\
\hline \multirow{6}{*}{ Communication in the mother tongue } & Active listener & & & & & & \\
\hline & Ability to be influential/persuasive & 5.0 & \multirow{5}{*}{5.2} & 0.75 & \multirow{5}{*}{0.950703826} & 5 & \multirow{5}{*}{5} \\
\hline & Ability to provide feedback & 5.3 & & 0.98 & & 6 & \\
\hline & Ability to communicate effectively & 5.6 & & 0.92 & & 6 & \\
\hline & Negotiation skills & 5.1 & & 1.11 & & 5 & \\
\hline & Good self-presentation skills & 5.0 & & 0.90 & & 5 & \\
\hline \multirow{2}{*}{ Ability to communicate in foreign languages } & English language & 5.2 & \multirow{2}{*}{5.2} & 1.03 & \multirow{2}{*}{1.11} & 5 & \multirow{2}{*}{5} \\
\hline & Other foreign languages & 5.3 & & 1.17 & & 5 & \\
\hline \multirow{3}{*}{ Mathematical and science competences } & Analytical skills & 4.8 & \multirow{3}{*}{5.1} & 1.13 & \multirow{3}{*}{1.12} & 4 & \multirow{3}{*}{5} \\
\hline & $\begin{array}{l}\text { Ability to identify key information within } \\
\text { information overload }\end{array}$ & 5.2 & & 1.05 & & 5 & \\
\hline & Numeracy skills & 5.2 & & 1.12 & & 6 & \\
\hline Technology competencies & $\begin{array}{l}\text { Ability to use technology/computer/network, } \\
\text { MS Office }\end{array}$ & 5.2 & 5.2 & 0.973447482 & 0.97 & 5 & 5 \\
\hline \multirow{6}{*}{ Ability to learn } & Quick learner & 5.1 & \multirow{12}{*}{5.1} & 0.85 & \multirow{6}{*}{0.98} & 5 & \multirow{6}{*}{5} \\
\hline & Problem solving & 5.0 & & 0.96 & & 5 & \\
\hline & Ability to draw conclusions & 5.4 & & 0.98 & & 6 & \\
\hline & Quick decision maker & 5.0 & & 0.99 & & 5 & \\
\hline & Clear career path & 5.2 & & 1.11 & & 5 & \\
\hline & Participation in courses and trainings (CPD) & 4.9 & & 0.87 & & 5 & \\
\hline \multirow{6}{*}{ Social and civil competences } & Human resource management & 4.7 & & 0.87 & & 5 & \\
\hline & Ability to build relationships with customers & 4.7 & & 0.87 & & 4 & \\
\hline & Ability to be team player & 4.9 & & 0.93 & & 5 & \\
\hline & Interpersonal skills & 4.9 & & 0.82 & & 5 & \\
\hline & Ethics & 5.0 & & 0.71 & & 5 & \\
\hline & Empathy & 4.7 & & 0.97 & & 4 & \\
\hline
\end{tabular}


Table 4. Cont.

\begin{tabular}{|c|c|c|c|c|c|c|c|}
\hline \multicolumn{2}{|c|}{ Poland and Slovakia (Cross-Border Area) } & Average & $\begin{array}{l}\text { Average from } \\
\text { Category }\end{array}$ & $\begin{array}{l}\text { Standard } \\
\text { Deviation }\end{array}$ & $\begin{array}{l}\text { Standard } \\
\text { Deviation }\end{array}$ & Median & Median \\
\hline \multirow{3}{*}{ Initiative and entrepreneurship } & $\begin{array}{l}\text { Ability to organize work and effective time } \\
\text { management }\end{array}$ & 4.9 & \multirow{3}{*}{4.9} & 0.87 & \multirow{3}{*}{0.88} & 5 & \multirow{3}{*}{5} \\
\hline & Flexibility and adaptability & 4.8 & & 0.88 & & 4.5 & \\
\hline & Entrepreneurship & 5.1 & & 0.87 & & 5 & \\
\hline Cultural awareness & $\begin{array}{l}\text { Ability to work with people from different } \\
\text { backgrounds, countries, cultures }\end{array}$ & 5.1 & 5.1 & 1.05 & 1.051475154 & 5 & 5 \\
\hline \multirow{3}{*}{ Additional competences } & $\begin{array}{l}\text { Industry expertise and directional expertise } \\
\text { adequate to the current needs of enterprises }\end{array}$ & 5.0 & \multirow{3}{*}{5.2} & 0.99 & \multirow{3}{*}{1.03} & 5 & \multirow{3}{*}{5} \\
\hline & $\begin{array}{l}\text { Certificates, awards confirming completion } \\
\text { of studies, programs, specific skills }\end{array}$ & 5.0 & & 0.73 & & 5 & \\
\hline & Experience & 5.54 & & 1.22 & & 5 & \\
\hline \multicolumn{2}{|c|}{ Poland (Cross-Border Area) } & Average & $\begin{array}{l}\text { Average from } \\
\text { Category }\end{array}$ & $\begin{array}{c}\text { Standard } \\
\text { Deviation }\end{array}$ & $\begin{array}{l}\text { Standard } \\
\text { Deviation }\end{array}$ & Median & Median \\
\hline \multirow{6}{*}{ Communication in the mother tongue } & Active listener & 5.1 & \multirow{6}{*}{5.2} & 0.84 & \multirow{6}{*}{0.97} & 5 & \multirow{6}{*}{5} \\
\hline & Ability to be influential/persuasive & 5.0 & & 0.72 & & 5 & \\
\hline & Ability to provide feedback & 5.3 & & 1.07 & & 6 & \\
\hline & Ability to communicate effectively & 5.6 & & 0.93 & & 6 & \\
\hline & Negotiation skills & 5.1 & & 1.11 & & 5 & \\
\hline & Good self-presentation skills & 5.2 & & 0.96 & & 5 & \\
\hline \multirow{2}{*}{ Ability to communicate in foreign languages } & English language & 5.1 & \multirow{2}{*}{5.2} & 1.14 & \multirow{2}{*}{1.18} & 5 & \multirow{2}{*}{5} \\
\hline & Other foreign languages & 5.3 & & 1.22 & & 5 & \\
\hline \multirow{3}{*}{ Mathematical and science competencies } & Analytical skills & 5.0 & \multirow{3}{*}{5.1} & 1.15 & \multirow{3}{*}{1.09} & 4 & \multirow{3}{*}{5} \\
\hline & $\begin{array}{l}\text { Ability to identify key information within } \\
\text { information overload }\end{array}$ & 5.4 & & 0.98 & & 6 & \\
\hline & Numeracy skills & 5.0 & & 1.09 & & 5 & \\
\hline Technology competences & $\begin{array}{l}\text { Ability to use technology/computer/network, } \\
\text { MS Office }\end{array}$ & 5.1 & 5.1 & 0.93 & 0.93 & 5 & 5 \\
\hline
\end{tabular}


Table 4. Cont

\begin{tabular}{|c|c|c|c|c|c|c|c|}
\hline \multicolumn{2}{|c|}{ Poland and Slovakia (Cross-Border Area) } & Average & $\begin{array}{l}\text { Average from } \\
\text { Category }\end{array}$ & $\begin{array}{c}\text { Standard } \\
\text { Deviation }\end{array}$ & $\begin{array}{c}\text { Standard } \\
\text { Deviation }\end{array}$ & Median & Median \\
\hline \multirow{6}{*}{ Ability to learn } & Quick learner & 5.2 & \multirow{6}{*}{5.1} & 0.78 & \multirow{6}{*}{1.01} & 5 & \multirow{6}{*}{5} \\
\hline & Problem solving & 4.8 & & 1.03 & & 5 & \\
\hline & Ability to draw conclusions & 5.5 & & 1.02 & & 6 & \\
\hline & Quick decision maker & 5.1 & & 0.97 & & 5 & \\
\hline & Clear career path & 5.3 & & 1.12 & & 6 & \\
\hline & Participation in courses and trainings (CPD) & 4.8 & & 0.88 & & 5 & \\
\hline \multirow{6}{*}{ Social and civil competences } & Human resource management & 4.7 & \multirow{6}{*}{4.8} & 0.82 & \multirow{6}{*}{0.90} & 5 & \multirow{6}{*}{5} \\
\hline & Ability to build relationships with customers & 4.9 & & 0.90 & & 5 & \\
\hline & Ability to be team player & 4.8 & & 0.95 & & 4 & \\
\hline & Interpersonal skills & 4.9 & & 0.89 & & 5 & \\
\hline & Ethics & 5.2 & & 0.67 & & 5 & \\
\hline & Empathy & 4.6 & & 0.99 & & 4 & \\
\hline \multirow{3}{*}{ Initiative and entrepreneurship } & $\begin{array}{l}\text { Ability to organize work and effective time } \\
\text { management }\end{array}$ & 4.9 & \multirow{3}{*}{4.9} & 0.86 & \multirow{3}{*}{0.91} & 5 & \multirow{3}{*}{5} \\
\hline & Flexibility and adaptability & 4.9 & & 0.91 & & 5 & \\
\hline & Entrepreneurship & 5.1 & & 0.93 & & 5 & \\
\hline Cultural awareness & $\begin{array}{l}\text { Ability to work with people from different } \\
\text { backgrounds, countries, cultures }\end{array}$ & 5.3 & 5.3 & 1.15 & 1.15 & 5 & 5 \\
\hline \multirow{3}{*}{ Additional competences } & $\begin{array}{l}\text { Industry expertise and directional expertise } \\
\text { adequate to the current needs of enterprises }\end{array}$ & 5.2 & \multirow{3}{*}{5.1} & 1.11 & \multirow{3}{*}{1.03} & 5 & \multirow{3}{*}{5} \\
\hline & $\begin{array}{l}\text { Certificates, awards confirming completion } \\
\text { of studies, programs, specific skills }\end{array}$ & 4.8 & & 0.62 & & 5 & \\
\hline & Experience & 5.24 & & 1.21 & & 5 & \\
\hline \multicolumn{2}{|c|}{ Slovakia (Cross-Border Area) } & Average & $\begin{array}{l}\text { Average from } \\
\text { Category }\end{array}$ & $\begin{array}{l}\text { Standard } \\
\text { Deviation }\end{array}$ & $\begin{array}{c}\text { Standard } \\
\text { Deviation }\end{array}$ & Median & Median \\
\hline
\end{tabular}


Table 4. Cont.

\begin{tabular}{|c|c|c|c|c|c|c|c|}
\hline Poland and Slovakia & (Cross-Border Area) & Average & $\begin{array}{l}\text { Average from } \\
\text { Category }\end{array}$ & $\begin{array}{l}\text { Standard } \\
\text { Deviation }\end{array}$ & $\begin{array}{l}\text { Standard } \\
\text { Deviation }\end{array}$ & Median & Median \\
\hline \multirow{6}{*}{ Communication in the mother tongue } & Active listener & 5.1 & \multirow{6}{*}{5.1} & 0.89 & \multirow{6}{*}{0.93} & 5 & \multirow{6}{*}{5} \\
\hline & Ability to be influential/persuasive & 5.0 & & 0.77 & & 5 & \\
\hline & Ability to provide feedback & 5.4 & & 0.89 & & 6 & \\
\hline & Ability to communicate effectively & 5.5 & & 0.89 & & 6 & \\
\hline & Negotiation skills & 5.1 & & 1.11 & & 5 & \\
\hline & Good self-presentation skills & 4.9 & & 0.81 & & 5 & \\
\hline \multirow{2}{*}{ Ability to communicate in foreign languages } & English language & 5.4 & \multirow{2}{*}{5.1} & 0.89 & \multirow{2}{*}{1.02} & 5 & \multirow{2}{*}{5.5} \\
\hline & Other foreign languages & 5.4 & & 1.13 & & 6 & \\
\hline \multirow{3}{*}{ Mathematical and science competencies } & Analytical skills & 4.6 & \multirow{3}{*}{5.0} & 1.09 & \multirow{3}{*}{1.14} & 4 & \multirow{3}{*}{5} \\
\hline & $\begin{array}{l}\text { Ability to identify key information within } \\
\text { information overload }\end{array}$ & 5.0 & & 1.08 & & 5 & \\
\hline & Numeracy skills & 5.4 & & 1.098362417 & & 6 & \\
\hline Technology competencies & $\begin{array}{l}\text { Ability to use technology/computer/network, } \\
\text { MS Office }\end{array}$ & 5.3 & 5.3 & 1.00 & 1.00 & 6 & 6 \\
\hline \multirow{6}{*}{ Ability to learn } & Quick learner & 5.0 & \multirow{6}{*}{5.1} & 0.91 & \multirow{6}{*}{0.95} & 5 & \multirow{6}{*}{5} \\
\hline & Problem solving & 5.1 & & 0.86 & & 5 & \\
\hline & Ability to draw conclusions & 5.3 & & 0.93 & & 6 & \\
\hline & Quick decision maker & 5.0 & & 0.99 & & 5 & \\
\hline & Clear career path & 5.0 & & 1.07 & & 5 & \\
\hline & Participation in courses and trainings (CPD) & 5.0 & & 0.87 & & 5 & \\
\hline \multirow{6}{*}{ Social and civil competences } & Human resource management & 4.7 & \multirow{6}{*}{4.9} & 0.92 & \multirow{6}{*}{0.85} & 4 & \multirow{6}{*}{5} \\
\hline & Ability to build relationships with customers & 5.0 & & 0.94 & & 5 & \\
\hline & Ability to be team player & 5.1 & & 0.89 & & 5 & \\
\hline & Interpersonal skills & 4.8 & & 0.75 & & 5 & \\
\hline & Ethics & 4.9 & & 0.71 & & 5 & \\
\hline & Empathy & 4.8 & & 0.94 & & 5 & \\
\hline
\end{tabular}


Table 4. Cont

\begin{tabular}{|c|c|c|c|c|c|c|c|}
\hline Poland and Sl & (Cross-Border Area) & Average & $\begin{array}{l}\text { Average from } \\
\text { Category }\end{array}$ & $\begin{array}{l}\text { Standard } \\
\text { Deviation }\end{array}$ & $\begin{array}{l}\text { Standard } \\
\text { Deviation }\end{array}$ & Median & Median \\
\hline \multirow{3}{*}{ Initiative and entrepreneurship } & $\begin{array}{l}\text { Ability to organize work and effective time } \\
\text { management }\end{array}$ & 5.0 & \multirow{3}{*}{4.9} & 0.87 & \multirow{3}{*}{0.85} & 5 & \multirow{3}{*}{5} \\
\hline & Flexibility and adaptability & 4.7 & & 0.83 & & 4 & \\
\hline & Entrepreneurship & 5.1 & & 0.79 & & 5 & \\
\hline Cultural awareness & $\begin{array}{l}\text { Ability to work with people from different } \\
\text { backgrounds, countries, cultures }\end{array}$ & 5.0 & 5.0 & 0.91 & 0.91 & 5 & 5 \\
\hline \multirow{3}{*}{ Additional competences } & $\begin{array}{l}\text { Industry expertise and directional expertise } \\
\text { adequate to the current needs of enterprises }\end{array}$ & 4.8 & \multirow{3}{*}{5.3} & 0.83 & \multirow{3}{*}{1.03} & 5 & \multirow{3}{*}{5} \\
\hline & $\begin{array}{l}\text { Certificates, awards confirming completion } \\
\text { of studies, programs, specific skills }\end{array}$ & 5.2 & & 0.78 & & 5 & \\
\hline & Experience & 5.84 & & 1.15 & & 5 & \\
\hline
\end{tabular}

Source: Self-analysis. 
The differences in the evaluation of Polish and Slovakian respondents were on average 0.1 points. Hence, it is possible to assume that both the competences and expectations with relation to the labour market are similar. This is confirmed by the adopted assumptions relating to the possibilities of cross-border cooperation between both countries in terms of the exchange of employees and workplaces. The research was of a pilot project nature and in order to gain a broader spectrum it shall be repeated on a larger sample group.

In a preliminary answer to the question relating to the formal tools that can support the acquisition of the competences among the graduates of business schools, it is possible to recommend a range of programs within the framework of cross-border cooperation. In terms of enhancing the efficiency of the policies of cohesion, the program of INTERREG EUROPE advocates the exchange of experiences in the sphere of aims among the partners of the entire EU, in order to render the identification and distribution of good practices possible with the aim of transferring them to mainly operative programs within the framework of investments on behalf of growth and employment, while also in justified cases to the programs of the European Territorial Cooperation (ETC). The aforementioned aspects shall be realized by means of facilitating and supporting the process of expanding knowledge in the sphere of policies, conveying knowledge and transferring good practices between the regional and local authorities, as well as other entities of a regional significance. The program encompasses the whole territory of the EU in its scope, as well as Norway and Switzerland. It is co-financed by funds from the European Regional Development Fund (ERDF). The budget of the program for the period of 2014-2020 amounted to 359 m euro. INTERREG EUROPE is one of the instruments that serve the implementation of the policies of cohesion in the EU. In executing this policy, the EU pursues the harmonious development in the EU by means of strengthening its economic, social and territorial cohesion in order to stimulate development in the regions of the EU and in member countries. The aim of this policy is to restrict the disproportion existing between the regions of EU from the viewpoint of their economic development, as well as social development and eco-development, while taking account of their particular features and opportunities of a territorial nature. In the period of financing which encompassed the years 2014-2020 the policy of cohesion shall be directed towards supporting the execution of the aims of the strategy "Europe 2020".

"Europe 2020" is a strategy whose task is to transform the EU into a smart economy of sustainable development that favors social inclusion while ensuring a high level of employment, efficiency and social cohesion. "Europe 2020" is a program that is designated for the EU as a whole by taking account of various starting points, needs and features that are characteristic of the member states with the aim of promoting economic growth in the entire EU. Europe 2020 has three mutually complementary priorities: Smart growth: Development of an economy based on knowledge and innovations; sustainable development: Supporting an economy that avails of resources effectively, more environmentally friendly; and more competitive, development that favors social inclusion: Supporting an economy of a high level of employment that ensures social cohesion and territorial cohesion.

The Partnership on Cross-Border Labour Market of Poland and Slovakia (POPRAD-DUNAJEC) the longstanding cooperation between Polish and Slovakian institutions operating on the cross-border labor market bore fruition with the establishment of this partnership. Its initiators were as follows: The Provincial Labour Office of Cracow, the Administrative Labour Office of the Administrative District of Nowosadecki in Nowy Sacz, as well as the Labour Office, Social Issues and Family Issues in Stara Lubovna in the Slovakian Republic. This partnership was founded as a result of the project executed in the years 2011-2013 within the framework of the Program of Cross-Border Cooperation between the Polish Republic and the Slovakian Republic in 2007-2013, co-financed by the EU with the European Regional Development Fund. This partnership consists of 66 Polish and Slovakian institutions operating on behalf of the labor market.

The working group referring to the work and social policies of the Polish-Slovakian Inter-Governmental Commission relating to Cross-Border Cooperation-the Provincial Labour Office in Cracow controls the work of the employee groups with regard to the work and social policies of the 
Polish-Slovakian Inter-Governmental Commission relating to Cross-Border Cooperation. The working group includes the representatives of the Provincial Labour Office in Katowice and Rzeszów, as well as the representatives of the Labour Offices and Social and Family Issues from the Presov and Zyliński country areas of Slovakia.

Cross-Border Job Fairs, Education and Entrepreneurship—presentation of firms and job offers in the country and abroad, while also educational and training propositions, individual consultations on the issue of the possibilities of establishing business activities. The following entities participated in the event: The Main Labour Office, of Social and Family Issues in Bratislava, Voluntary Work Corps and the Provincial Labour Office in Cracow. The motto of the annual job fair is as follows: "We live in the Polish-Slovakian borderland areas and we practically do not notice the border between our countries. We may resolve problems together, while also build and act together. This also means that the inhabitants of our region may take up employment on the Slovakian side and our southern neighbours on our territory. The challenge we are facing is that of joint education, particularly in terms of professional education in the desired areas of the borderland, namely in tourist services".

\section{Discussion}

The applied research procedure combines the analysis of the literature with empirical research. The adopted method allowed a numerical description of trends, attitudes and opinions in a selected group. It also facilitated a comparison of the results of the studies of Polish graduates and Slovakian graduates.

The research conducted in the sphere of shaping the cross-border labour market for the graduates of higher education colleges shall be continued. Analysis of a wider research group shall be prepared in order to confirm the stipulated preliminary findings. Guidelines for study programs in Polish and Slovakian schools shall be prepared and subjected to evaluation, which should facilitate an even closer cross-border cooperation.

Subsequently, the extension of research to other cross-border areas between Poland and its neighboring countries is planned, which shall avail of an analogous tool to indicate the similarities and differences in terms of the evaluation of the necessary competences on further labor markets.

Author Contributions: Writing—original draft, M.M.S., K.S.-W. and Z.J.M.

Funding: This research received no external funding.

Conflicts of Interest: The authors declare no conflicts of interest.

\section{References}

1. Szadkowska, E. Pojęcie współpracy transgranicznej. In Wspótpraca Transgraniczna; Perkowski, M., Ed.; Aspekty Prawno-Ekonomiczne, Fundacja Prawo i Partnerstwo: Białystok, Poland, 2010; p. 15.

2. European Outline Convention on Trans-frontier Co-operation between Territorial Communities or Authorities; European Treaty Series: Madrid, Spain, 1980.

3. European Territorial Cooperation Work Package 11. July 2016. Available online: https://ec.europa.eu/regiona 1_policy/sources/docgener/evaluation/pdf/expost2013/wp11_final_report.pdf (accessed on 12 May 2018).

4. Europejska Konwencja Ramowa o współpracy Transgranicznej między wspólnotami i władzami Terytorialnymi (1980) Dz.U. 1993 nr 61 poz. 287. Available online: http://prawo.sejm.gov.pl/isap.nsf/home.xsp (accessed on 4 September 2019).

5. ETC -European Territorial Cooperation. 2018. Available online: https://ec.europa.eu/regional_policy/en/poli cy/cooperation/european-territorial/ (accessed on 12 May 2018).

6. Halleux, V. EU Legislation in Progress 2021-2027 MFF; European Parliamentary Research Service: Rue Wiertz, Belgium, 2018.

7. Kentnowska, K. Rozwój form współpracy samorządów na poziomie międzynarodowym. In Formy Wspótdziałania Jednostek Samorząu Terytorialnego; Dolnicki, B., Ed.; Wolters Kluwer: Warszawa, Poland, 2012; p. 238. 
8. Kurowska-Pysz, J. Shaping of competencies of managers in academic incubators of entrepreneurship in Poland. Organizacija 2014, 47, 52-65. [CrossRef]

9. Szczepańska-Woszczyna, K. Determinants of innovation activities in small and medium-sized enterprises in Poland. J. Adv. Res. Manag. 2014, 10, 65-73.

10. Krzymuski, M.; Kubicki, P. EUWT 2.0? Reforma rozporządzenia o europejskich ugrupowaniach współpracy terytorialnej szansą na ożywienie współpracy transgranicznej podmiotów publicznych. Samorz. Teryt. 2015, 6, 23-37.

11. Kurowska-Pysz, J.; Szczepańska-Woszczyna, K. The analysis of the determinants of sustainable cross-border cooperation and recommendations on its harmonization. Sustainability 2017, 9, 2226. [CrossRef]

12. Suchacek, J.; Walancik, M.; Wróblewski, Ł.; Urminský, J.; Drastichová, M.; Šotkovský, I. Management of municipal development of Euroregion Beskydy in Poland and Czechia. Pol. J. Manag. Stud. 2018, 18, 365-378. [CrossRef]

13. Suchacek, J. Large enterprise branches: The case of the Czech Republic. Econ. Sociol. 2015, 8, 82-93. [CrossRef] [PubMed]

14. EUROREGION BAŁTYK 2020. 2010. Available online: http://eurobalt.org/wp-content/uploads/2008/02/EU ROREGION\%20BALTIC\%202020_PL_fin.pdf (accessed on 12 May 2018).

15. Kurowska-Pysz, J.; Castanho, R.A.; Naranjo Gómez, J.M. Cross-border cooperation-The barriers analysis and the recommendations. Pol. J. Manag. Stud. 2018, 17, 134-147. [CrossRef]

16. Rozporządzenie (WE) nr 1082/2006 Parlamentu Europejskiego i Rady z dnia 5 lipca 2006 r. w sprawie utworzenia Europejskiego Ugrupowania Współpracy Terytorialnej, Dz. Urz. WE L 210/19 z 31.07.2006 r. Available online: http://prawo.sejm.gov.pl/isap.nsf/home.xsp (accessed on 4 September 2019).

17. Rozporządzenie Parlamentu Europejskiego i Rady (UE) nr 1302/2013 z dnia 17 grudnia 2013 r. Dz. Urz. UE L 347/303 z 20.12.2013 r. Available online: http://prawo.sejm.gov.pl/isap.nsf/home.xsp (accessed on 4 September 2019).

18. Korczak, J.; Nowacki, K. Formy współdziałania komunalnego (gmin i powiatów) w obszarze przygranicznym. Wybrane zagadnienia. In Transgraniczna Wspótpraca Społeczności Lokalnej i Władz Między Polską a Niemcami; Albrecht, E., Nowacki, K., Eds.; Berli: Berlin, Germany, 2006; p. 197.

19. Jendrośka, J. Prawne podstawy transgranicznego uczestnictwa władz i społeczności lokalnych w podejmowaniu decyzji dotyczących ochrony środowiska. (red.). In Transgraniczna Wspótpraca Społeczności Lokalnej i Władz Między Polska a Niemcami; Albrecht, E., Nowacki, K., Eds.; Berli: Berlin, Germany, 2006; p. 13.

20. Levrat, N. Legal Aspects of Trans-frontier Co-operation, Building a New Europe. In Trans-Frontier Co-Operation in Central Europe, Prague-Budapest-Warsaw-New York-Kosice 1996, s. 30. Podaje za: A. Mikołajczyk, Podstawowe Pojęcia; Hudak, V., Brodecki, Z., Eds.; Regiony: Warszawa, Poland, 2005; p. 209.

21. Kurowska-Pysz, J. Wiedza, innowacje, konkurencyjność-uwarunkowania działalności przemysłowego klastra technologicznego na pograniczu polsko-słowackim; Wydawnictwo CEIT AS: Żylina, Slovakia, 2013; p. 73.

22. Mikołajczyk, A. Podstawy Prawne; Regiony: Warszawa, Poland, 2005; p. 211.

23. Czarnow, S. Niektóre aspekty prawne współpracy transgranicznej i euroregionów. Państwo i Prawo 1997, 10, 55-71.

24. Kusiak-Winter, R. Współpraca transgraniczna gmin Polski i Niemiec. Stud. Adm. Wrocław 2011, 11, 31-32.

25. Prawo o stowarzyszeniach (1989) z dnia 7 kwietnia 1989 r., Dz.U. 1989 nr 20 poz. 104. Available online: http://prawo.sejm.gov.pl/isap.nsf/home.xsp (accessed on 4 September 2019).

26. Longman Dictionary, Longman, Rev. ed.; March 1989; p. 125.

27. Słownik Języka Polskiego; Wydawnictwo Naukowe PWN: Warszawa, Poland, 2005; p. 348.

28. Ferris, G.R.; Rowland, K.M.; Buckley, R.M. Human Resources Management: Perspectives and Issu; Allyn \& Bacon: Boston, MA, USA, 1990.

29. Hartog, J. Capabilities, Allocation and Earnings; Kluwer: Boston, MA, USA, 1992.

30. Mingotaud, F. Sprawny Kierownik, Techniki Osiagania Sukcesu; Poltext: Warszawa, Poland, 1994; pp. 72-75.

31. Thierry, D.; Sauret, C.; Monod, N. Zatrudnienie i Kompetencje w Przedsiębiorstwie w Procesach Zmian; Poltext: Warszawa, Poland, 1994; p. 6.

32. Lévy-Leboyer, C. Kierowanie Kompetencjami-Bilanse Doświadczeń Zawodowych; Poltext: Warszawa, Poland, 1997; p. 19.

33. Masten, A.S.; Coatsworth, J.D. The development of competence in favourable and unfavourable environments. Lessons from research on successful children. Am. Psychol. 1988, 53, 205-220. [CrossRef] 
34. Pocztowski, A. Zarzadzanie Zasobami Ludzkimi.; Strategie-Procesy-Metody, Polskie Wydawnictwo Ekonomiczne: Warszawa, Poland, 2003; p. 153.

35. Bratnicki, M. Kompetencje przedsiębiorstwa; Agencja Wydawnicza Placet: Warszawa, Poland, 2000; p. 23.

36. Oleksyn, T. Zarzadzanie Kompetencjami. Teoria i Praktyka; Wolters Kluwer: Warszawa, Poland, 2010; pp. 17-18.

37. Kim, S.Y.; Kim, Y.K. A Study on the Classification of Nursing Management Competencies and Development of related Behavioral Indicators in Hospitals. J. Korean Acad. Nurs. 2016, 46, 375-389. [CrossRef] [PubMed]

38. Lee, H.W.; Park, S.H. Analysis of academic competency and development of support program for undergraduate students at Seoul National University. Core Competency Educ. Res. 2017, 2, 87-105.

39. Green, F. The Growing Importance of Generic Skills. Available online: http://www.beyondcurrenthorizons. org.uk/the-growing-importance-of-generic-skills/ (accessed on 12 May 2018).

40. Heijke, H.; Meng, C.; Ramaekers, G. An Investigation into the Role of Human Capital Competences and Their Pay-Off. Int. J. Manpow. 2003, 24, 750-773. [CrossRef]

41. Becker, G.S. Human Capital: A Theoretical and Empirical Analysis, with Special Reference to Education; University of Chicago: Chicago, IL, USA, 1964.

42. Kellermann, P. Acquired and Required Competencies of Graduates. In Careers of University Graduates: Views and Experiences in Comparative Perspectives; Teichler, U., Ed.; Kluwer: Dordrecht, The Netherlands, 2007.

43. Heijke, H.; Meng, C.; Ramaekers, G. An Investigation into the Role of Human Capital Competences and Their Pay-Off, Working Paper ROA-RM-2002/3E, Maastricht University, Research Centre for Education and the Labour Market. 2003. Available online: http://arnop.unimaas.nl/show.cgi?fid716 (accessed on 15 January 2015).

44. OECD. Technical Report of the Survey of Adult Skills (PIAAC). Available online: http://www.oecd.org/site/ piaac/Technical\%20Report17OCT13.pdf (accessed on 13 January 2019).

45. Karamatić Brčić, M.; Perin, V. Reflection on key competences for lifelong learning: A structral analysis, of teachers study programmes in the republic of Croatia. Andragoškaspoznanja 2014, 20, 23-40.

46. Popescu, A. Lifelong Learning in the Knowledge Economy: Considerations on the Lifelong Learning System in Romania from a European Perspective. Revista de Cercetare si Interventie Social 2012, 37, 49-76.

47. European Commission. The European Employment Strategy; Investing in People: Brussels, Belgium, 1999.

48. The Lisbon Special European Council. Towards a Europe of innovation and knowledge 2018. Available online: https://eit.europa.eu/sites/default/files/amended_2018_call_for_proposals.pdf (accessed on 13 January 2019).

49. EACEA (Education, Audiovisual \& Culture Executive Agency). Lifelong Learning Program (2007-2013); European Union: Brussels, Belgium, 2003.

50. European Commission. Key Competences for Lifelong Learning; Recommendation of the members of the European Parliament and the Council, (2006/962/EC; 18 December); Commission of the European Communities: Brussels, Belgium, 2016.

51. EU (2018a) Council Recommendation on Key Competencies for Lifelong Learning. Available online: https://ec.europa.eu/education/education-in-the-eu/council-recommendation-on-key-competenc es-for-lifelong-learning_en (accessed on 13 January 2019).

52. EU (2018b) Commission Staff Working Document Accompanying the document Proposal for a Council Recommendation on Key Competences for Lifelong Learning. Available online: https://eur-lex.europa.eu/le gal-content/EN/TXT/?uri=SWD:2018:0014:FIN (accessed on 13 January 2019).

53. Eurosta. Young people on the labour market-Statistics. 2018. Available online: https: //ec.europa.eu/eurostat/statistics-explained/index.php/Young_people_on_the_labour_market_-_stati stics\#High_education_means_high_employment_rate (accessed on 22 February 2019).

54. Stuss, M. Corporate Social Responsibility as an Employer Branding Tool: The Study Results of Selected Companies Listed on GPW. Int. J. Contemp. Manag. 2018, 17, 249-267. [CrossRef]

55. Creswell, J.W.L. Qualitative Inquiry and Research Design, Choosing among 5 Approached; Sage Publication: Saunders Oaks, CA, USA, 2013.

(C) 2019 by the authors. Licensee MDPI, Basel, Switzerland. This article is an open access article distributed under the terms and conditions of the Creative Commons Attribution (CC BY) license (http://creativecommons.org/licenses/by/4.0/). 